\title{
Umbilical Cord Blood Natural Killer Cells, Their Characteristics, and Potential Clinical Applications
}

\author{
Anushruti Sarvaria' ${ }^{1,2}$, Dunia Jawdat ${ }^{3}$, J. Alejandro Madrigal ${ }^{1,2}$ and Aurore Saudemont ${ }^{1,2 *}$ \\ ${ }^{1}$ Anthony Nolan Research Institute, London, UK, ${ }^{2}$ Cancer Institute, University College London, London, UK, \\ ${ }^{3}$ King Abdullah International Medical Research Center, Riyadh, Saudi Arabia
}

Natural killer (NK) cells are lymphocytes of the innate immune system able to kill different targets such as cancer cells and virally infected cells without prior activation making then attractive candidates for cancer immunotherapy. Umbilical cord blood (UCB) has become a source of hematopoietic stem cells for transplantation but as we gain a better understanding of the characteristics of each immune cell that UCB contains, we will also be able to develop new cell therapies for cancer. In this review, we present what is currently known of the phenotype and functions of UCB NK cells and how these cells could be used in the future for cancer immunotherapy.

OPEN ACCESS

Edited by: Antoine Toubert,

Paris Diderot University, France

Reviewed by:

Subramaniam Malarkannan, Medical College of Wisconsin, USA Amir Ahmed Toor, Virginia Commonwealth

University, USA

${ }^{*}$ Correspondence:

Aurore Saudemont aurore.saudemont@anthonynolan.org

Specialty section: This article was submitted to Alloimmunity and Transplantation,

a section of the journal

Frontiers in Immunology

Received: 18 January 2017 Accepted: 07 March 2017

Published: 23 March 2017

Citation: Sarvaria A, Jawdat $D$, Madrigal JA and Saudemont A (2017) Umbilical Cord Blood Natural Killer Cells,

Their Characteristics, and Potential Clinical Applications.

Front. Immunol. 8:329. doi: 10.3389/fimmu.2017.00329
Keywords: natural killer cells, umbilical cord blood, immunotherapy, cancer, hematopoietic stem cells

\section{INTRODUCTION}

Natural killer (NK) cells are lymphocytes of the innate immune system that exhibit cytotoxicity toward cancer cells and virus-infected cells and have the capacity to produce cytokines such as interferon- $\gamma$ (IFN- $\gamma$ ) and tumor necrosis factor- $\alpha$ (TNF- $\alpha$ ) in response to stimuli. NK cells are defined as $\mathrm{CD} 56^{+} \mathrm{CD}^{-}$cells and can be divided into two main subsets according to their expression of CD56 and CD16. CD56 ${ }^{\mathrm{dim}} \mathrm{CD} 16^{+} \mathrm{NK}$ cells (CD56 ${ }^{\mathrm{dim}} \mathrm{NK}$ cells) are cytotoxic NK cells capable to mediate direct killing of target cells via exocytosis of granules containing granzyme B and perforin, activation of cell death pathways such as TRAIL or FAS/FAS-L or via antibody-dependent cellular cytotoxicity. CD56 $6^{\text {bright }} \mathrm{CD} 16^{- \text {llow }} \mathrm{NK}$ cells (CD56 $6^{\text {bright }} \mathrm{NK}$ cells) are the main cytokine-producing NK cells (1). In peripheral blood (PB), up to $90 \%$ of NK cells are CD56 $6^{\mathrm{dim}} \mathrm{NK}$ cells while most NK cells are CD56 ${ }^{\text {bright }} \mathrm{NK}$ cells in lymph nodes.

Natural killer cell functions are regulated by signals delivered through activating and inhibitory receptors. As opposite to T cells, NK cells are "ready to go" and can eliminate target cells without prior stimulation. However, stimulation of NK cells by cytokines leads to NK cell activation and enhanced functions, in particular enhanced cytolytic activity and proliferation. NK cells have long been considered potential candidates for cancer immunotherapy and their versatility makes them attractive cells to explore. Phase I clinical trials showed autologous NK cell therapies to be feasible and safe without adverse effects in patients with breast cancer or non-Hodgkin's lymphoma; however, these therapies had no or little impact on relapse rates (2). The potential impact of NK cell alloreactivity in hematopoietic stem cell transplantation (HSCT) was suggested by Valiante and Parham (3). The first evidence that allogeneic NK cells could exert strong anti-leukemic activity and impact on the outcome of haploidentical transplantation stems from the study of Ruggeri et al. (4) who reported NK cell alloreactivity against leukemic cells while reducing the risk of graft-versus-host disease (GvHD) in the context of human leukocyte antigen (HLA) mismatch settings. Other trials 
have showed that allogeneic NK cells alone can target different types of cancers such as acute myeloid leukemia (AML), melanoma, renal cell carcinoma, Hodgkin lymphoma (5), breast and ovarian cancer (6), or refractory lymphoma (7). The same group has shown the importance of NK cell expansion in vivo, which can be accomplished by infusion of interleukin (IL)-2. However, regulatory $\mathrm{T}$ cells were also found to compete for this cytokine and beneficial effects on NK cell expansion were observed when regulatory $\mathrm{T}$ cells could be depleted (8). Interestingly, other studies also have indicated that NK cell therapy could also be of interest to treat glioma (9) or neuroblastoma (10).

Umbilical cord blood (UCB) has become an established source of hematopoietic stem cells (11) for transplantation. Advantages for the use of UCB include low risk of viral transmission from donor to recipient, rapid availability of UCB units serving as an immediate "off-the-shelf" product, less stringent requirements for HLA matching, and lower risk of GvHD. However, UCB contains between 10 - and 100-fold fewer nucleated cells than other sources of HSC, limiting how many cells of interest can be retrieved from one UCB unit. Interestingly, NK cells are the first lymphocytes to recover after HSCT including after umbilical cord blood transplantation (UCBT) (12). In addition, NK cells are key effectors of the graft-versus-leukemia (GvL) effect. Especially after UCBT, as T cell immune reconstitution is delayed and there is no increased incidence of relapse, it is likely that NK cells are actually the main effectors of the GvL effect in the first year postUCBT. However, UCB also contains different types of immune cells including NK cells and as we learn more about their specific characteristics, we will identify the conditions which might benefit of an UCB NK cell therapy. This review focuses on providing an overview of the characteristics of UCB NK cells compared to NK cells from PB and explain how they could be used as a cell therapy to cancer.

\section{CHARACTERISTICS OF UCB NK CELLS}

Natural killer cells constitute up to $10 \%$ of lymphocytes in $\mathrm{PB}$ and up to $30 \%$ in $\operatorname{UCB}(13,14)$, and both CD56 $6^{\text {dim }}$ NK cells and CD56 ${ }^{\text {bright }} \mathrm{NK}$ cells can be found in PB and UCB with some groups reporting similar proportions of both subsets or higher frequency of CD56 $6^{\text {bright }}$ NK cells in UCB (14-16). Regarding the phenotype and functions of UCB NK cells, some groups have identified differences when compared to PB NK cells while others found them to be similar to PB NK cells (17) (Figure 1).

\section{Advantages of UCB-Derived NK Cells}

Aside from the higher percentage of NK cells present in UCB, the ability to cryopreserve UCB together with the ease of collecting UCB units offers a unique clinical advantage of making UCB an off-the-shelf source for NK cell immunotherapy. Moreover, a more rapid recovery of NK cells was reported after UCBT than PB HSCT $(18,19)$. This faster recovery could be explained by the fact that UCB contains different NK cell progenitor populations that have the capacity to differentiate into NK cells and are typically absent in PB (20-22). Further, PB and UCB NK cells produced similar amounts of IFN- $\gamma$ and TNF- $\alpha$ in response to different stimuli $(14,23)$ and could proliferate in response to cytokines such as IL-2 or IL-15 $(14,16,24)$ despite UCB NK cells exhibiting lower expression of the IL-2 receptor subunits and lower phosphorylation of STAT5 (25). Additionally, UCB NK cells have also been described to have a higher expression of the bone marrow homing receptor, CXCR4, compared to PB NK cells indicating that UCB NK cells may contain a greater potential to home to the bone marrow (14). Finally, IL-15 activated UCB NK cells have been reported to impact positively on UCB HSC engraftment by enhancing their migration and clonogenic capacity, and their engraftment in humanized animal model (26).
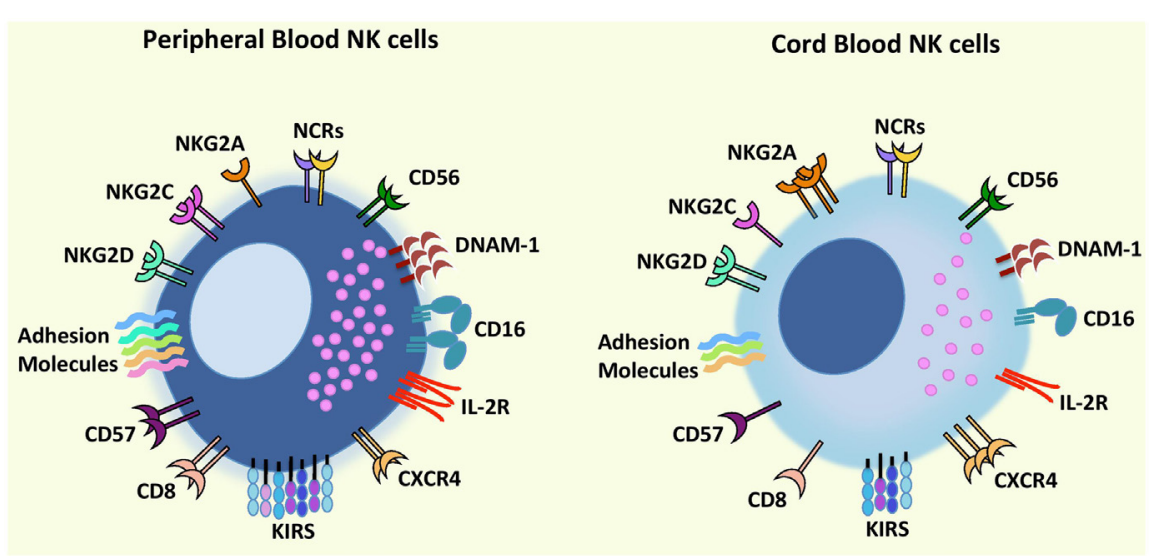

FIGURE 1 | Comparison of phenotypic characteristics between umbilical cord blood (UCB) natural killer (NK) cells and peripheral blood (PB) NK cells. In comparison to PB NK cells, UCB NK cells exhibit similar levels of CD56, NCRs (NKp46 and NKp30), and NKG2D but a lower expression of CD16, adhesion molecules (e.g., CD2, CD11a, CD18, CD62L), KIRs, DNAM-1, NKG2C, IL-2R, and CD57 and CD8 (receptors associated with terminal NK cell maturation) together with a higher expression of inhibitory receptor NKG2A indicating that UCB NK cells possess an immature phenotype and reduced cytotoxicity compared to PB NK cells. Further UCB NK cells have a higher expression of the bone marrow homing receptor, CXCR4, compared to PB NK cells proposing that cord blood NK cells may contain a greater potential to home to the bone marrow. Abbreviations: KIRs, killer-cell immunoglobulin-like receptors; NCRs, natural cytotoxicity receptors. 


\section{Drawbacks of UCB-Derived NK Cells}

The use of cord blood (CB) as a source of NK cells for immunotherapy, however, is also limited as a result of the low numbers and immaturity of CB NK cells. Although, UCB NK cells have been reported to be fully mature and functional $(16,27)$, some groups found them to have an immature phenotype $(14,28)$, exhibiting normal levels of degranulation but lower cytotoxicity against K562 cells as compared to PB NK cells $(14,23)$. This lower activity could be explained by the fact that UCB NK cells have decreased expression of certain adhesion molecules on their surface such as CD2, CD11a, CD18, and CD62L $(15,16)$, decreased expression of CD16 (15), decreased expression of perforin and granzyme B $(14,23)$, and lower killer-cell immunoglobulin-like receptors (KIRs) expression together with a higher expression of inhibitory molecules such as NKG2A when compared to PB NK cells indicating an immature phenotype $(14,23)$. However, activation with cytokines such as IL- 2 or IL-15 or the combination of IL-15 with IL-2 or IL-18 was able to restore or enhance their cytotoxicity to the levels observed for PB NK cells $(14,16,23,25$, 29). Moreover, although the frequencies of NK cells present in UCB is greater than PB (14), low numbers of UCB NK cells are obtained as a result of the limited volume of an UCB unit, which is a major obstacle in obtaining sufficient numbers of NK cells for clinical application. However, different strategies to increase NK cell doses have been developed.

\section{EXPANSION OF UCB NK CELLS}

A number of studies have recently explored different platforms to expand UCB NK cells. Increased NK cell numbers can be achieved either by large-scale expansion techniques using artificial antigen-presenting cell (aAPC) or cytokines including IL-2, IL-15, and/or FLT-3 ligand. One such strategy employed to expand purified UCB-derived NK cells on a large scale has been reported using good manufacturing practice (GMP)-grade K562-based aAPCs expressing membrane-bound IL-21 (30). Shah and colleagues have shown that following 14 days of culture in a gas permeable culture system, a 2,389-mean fold expansion of NK cells derived from frozen UCB was achieved. The expanded NK cells presented $>95 \%$ purity of $\mathrm{CD} 56^{+} \mathrm{CD}^{-} \mathrm{NK}$ cells and displayed efficient killing capacity against multiple myeloma in vitro and in vivo, highlighting the use of aAPCs as an attractive approach to generate large numbers of functionally competent UCB NK cells. A further strategy to evaluate the potential use of expanded NK cells was reported by using aAPCs in the form of genetically modified K562 cells expressing membrane-bound IL-15 and 41BBL (31). The aAPCs were cultured with CB mononuclear cells for 7 days, which led to the generation of expanded UCB NK cells that displayed increased expression of NK cell activating receptors, increased perforin and granzyme expression, and increased cytotoxicity against B-cell non-Hodgkin lymphoma in vitro and in vivo. The study merits the use of expanded NK cells for adoptive cellular therapy specifically to target relapse or refractory disease after UCBT. Finally, the use of irradiated Epstein-Barr virus-transformed lymphoblastoid cell lines and IL-2 was also recently reported to generate large numbers of $\mathrm{CD}^{+} 6^{+} \mathrm{NK}$ cells derived frozen UCB (32). The generated NK cells exhibited higher levels of cytotoxicity against K562 leukemic cells than expanded PB-derived NK cells (32). The unique advantage of this platform is that only $1 \mathrm{ml}$ of the UCB unit is selectively used to generate expanded NK cells for adoptive therapy and the remaining UCB from the same unit can be cryopreserved and used for future transplantation. It would be interesting to assess whether the use of the same UCB for early NK cell adoptive therapy and transplantation can help to prevent relapse and augment GvL post-UCBT.

\section{DIFFERENTIATION OF NK CELLS FROM UCB CD34+ CELLS}

Natural killer cells can be directly isolated from PB and UCB but an alternative to these cell sources is the differentiation of NK cells from HSC as a way to generate high numbers of cells (33). NK cells can be differentiated from CD34+ cells from the bone marrow, from embryonic stem cells, mobilized $\mathrm{PB}$, or $\mathrm{UCB}$ CD $34^{+}$cells. The expansion of NK cells derived from both fresh and frozen UCB CD $34^{+}$cells using a cocktail of cytokines in a culture system has also been described as an efficient system to generate large numbers of NK cells. We and others have reported the characteristics of $\mathrm{NK}$ cells produced in vitro from UCB CD34+ cells (34-36). These cells are mostly similar to PB NK cells with the exception that they express low levels of inhibitory receptors. However, NK cells produced in such a way have been shown to be functional, able to kill leukemic cell lines and patient cells in vitro and in vivo and produce cytokines in response to diverse stimuli (34, 36-38). Interestingly, NK cells produced in vitro have been shown to expand to high numbers while preserving their phenotype and functions after cryopreservation (39). Thus, frozen UCB CD $34^{+}$cells were found to be the best source of NK cells when compared to fresh UCB-derived CD $34^{+}$cells and frozen PB CD $34^{+}$cells and could therefore be a readily available off-the-shelf product for NK cell immunotherapy.

\section{NK Cells Alloreactivity in UCBT Setting}

Umbilical cord blood NK cells express both inhibitory and activating receptors, which are highly important in mediating self-tolerance or NK cell activity (40). Inhibitory receptors are part of the immunoglobulin superfamily including the KIRs, the immunoglobulin-like transcripts, and C-type lectin receptors CD94/NKG2A. Inhibitory receptors recognize the classical MHC class I molecules on target cells and inhibit NK cell lysis (41). Most KIRs are inhibitory receptors but a limited number of KIRs also function as activating receptors; however, the function and ligands of the later are less well understood. Since KIR genes are not on the same chromosome as HLA, these genes are inherited independently. This allows for donor and recipient HLA-matched UCBT and mismatching between KIRs and their ligands, maintaining the appropriate matching required for HSCT but providing NK cell alloreactivity, which triggers NK cell activation leading to tumor cell lysis (42). This phenomenon of NK cell alloreactivity was proposed as beneficial in reducing relapse after HSCT; however, variable results have been reported 
from different studies $(4,43-47)$. In UCBT setting, only few studies have evaluated the outcome of UCBT using mismatched KIR and its ligands (48-51) with only some of them reporting beneficial results $(52,53)$. KIR haplotype has also been shown to influence the outcome of HSCT. In this context, the higher the number of activating KIR a donor has the higher NK cell alloreactivity might be. Some studies have reported the beneficial effect of the donor $\mathrm{B}$ haplotype that contains more activating gene than a A haplotype on HSCT outcome in particular showing a lower incidence of relapse for patients with AML or lower GvHD incidence depending on the study considered (47, 54-56). Whether KIR haplotype can also influence UCBT outcome needs to be investigated.

Finally, NK cell licensing (57), arming/disarming (58), or education (59) is another factor to be considered. NK cells can express one or more inhibitory receptors recognizing HLA molecules. The process by which NK cells become functional and tolerant to self-HLA can be referred to as NK cell licensing and is defined by the fact that to be functional NK cells must express inhibitory receptors recognizing self-HLA. This concept has been well studied in mice and there are now also evidence in humans $(59,60)$. However, it has been reported that unlicensed NK cells are able to mount an immune response against cytomegalovirus in mice (61) and can kill neuroblastoma cells in humans (10). Therefore, moving forward it will be essential to gain a better understanding of the impact of NK cell licensing on their functions especially in the context of HSCT including UCBT.

\section{CURRENT CLINICAL STUDIES INVOLVING UCB NK CELLS}

Natural killer cells can be isolated from UCB based on CD56 purification methods. One step isolation method can be used in UCB as opposite to PB where two steps are needed in order to eliminate NKT cells. This is not necessary when considering UCB as it contains a very low percentage of that cell subset. In addition, UCB has the advantage of being readily available as UCB is cryopreserved and can be obtained from accredited UCB banks.
Therefore, a NK cell product derived from UCB has the potential to be off-the-shelf. Another advantage of UCB is that HLA is less stringent, although it is not clear what level of matching will be necessary to develop a third party NK cell product from UCB. However, because of the limited volume of blood collected from the umbilical cord there are only a limited number of NK cells that can be isolated from UCB. In addition, as they are immature and have lower functionality as compared to PB NK cells; taking UCB NK cells to the clinics will require a prior activation/expansion step. Several clinical trials are currently ongoing to evaluate the safety and feasibility of UCB NK cells as an "off the shelf product" in transplant and non-transplant settings (Table 1). GMP grade expansion methods for UCB NK cells are currently available as previously described. Notably, only a handful of clinical trials are currently ongoing and recruiting patients using the latest method to expand UCB NK cells to reach the cell dose required. Two clinical phase I studies aim to use expanded UCB NK cells for the treatment of patients with chronic lymphocytic leukemia (NCT01619761, NCT02280525), while another aims to evaluate NK cell therapy in the context of autologous HSCT for patients with myeloma (NCT01729091).

Only a few groups have focused on developing cell therapy approaches based on the differentiation of NK cells from HSC in vitro. However, NK cells produced in vitro have been shown to be safe and their use feasible when considered in the context of allogeneic HSCT (62). In addition, another trial, oNKord ${ }^{\circledR}$, is currently ongoing testing the use of NK cells produced in vitro from UCB CD34 ${ }^{+}$cells in patients with AML (EudraCT number 2010-018988-41).

\section{CONCLUDING REMARKS}

Immunotherapy is a promising treatment for different types of cancer allowing the possibility of personalized medicine for each cancer patient. UCB provides distinct advantages and is an increasingly attractive source for HSCT and cellular therapy. Despite low NK cell numbers within a single UCB unit and their immature phenotype, strategies to expand UCB NK cells using aAPCs or cytokines and feeder cells are

TABLE 1 | UCB NK cells currently in the clinic.

\begin{tabular}{|c|c|c|c|c|c|c|}
\hline $\begin{array}{l}\text { Clinical trial } \\
\text { identifier }\end{array}$ & Diseases & $\begin{array}{c}\text { Trial } \\
\text { phase }\end{array}$ & Type of transplant & Conditioning & Method of expansion & Sponsor \\
\hline NCT01619761 & $\begin{array}{l}\text { ALL, AML, CLL, CML, } \\
\text { HL, MDS, MM, NHL, SLL }\end{array}$ & 1 & $\begin{array}{l}\text { Double umbilical cord } \\
\text { blood transplantation }\end{array}$ & $\begin{array}{l}\text { Fludarabin, melphalan, } \\
\text { lenalidomide } \pm \text { rituximab }\end{array}$ & $\begin{array}{l}\text { Ex vivo expansion of NK cells } \\
\text { from } 20 \% \text { UCB unit fraction }\end{array}$ & $\begin{array}{l}\text { MD Anderson } \\
\text { Cancer Center }\end{array}$ \\
\hline NCT02280525 & $\begin{array}{l}\text { CLL, ALL, AML, CML, } \\
\mathrm{NHL}, \mathrm{HL}\end{array}$ & 1 & Non-HSCT & $\begin{array}{l}\text { Fludarabin, cyclophosphamide, } \\
\text { lenalidomide, and rituximab }\end{array}$ & $\begin{array}{l}\text { Ex vivo expansion of NK cells } \\
\text { from thawed from UCB unit }\end{array}$ & $\begin{array}{l}\text { MD Anderson } \\
\text { Cancer Center }\end{array}$ \\
\hline NCT01729091 & $\mathrm{MM}$ & $|/ /| \mid$ & Autologous & Melphalan, lenalidomide & $\begin{array}{l}\text { Ex vivo expansion of NK cells } \\
\text { from thawed from UCB unit }\end{array}$ & $\begin{array}{l}\text { MD Anderson } \\
\text { Cancer Center }\end{array}$ \\
\hline $\begin{array}{l}\text { EudraCT number } \\
2010-018988-41\end{array}$ & AML & 1 & Non-HSCT & Fludarabin, cyclophosphamide & $\begin{array}{l}\text { NK cells generated in vitro } \\
\text { from UCB progenitor cells }\end{array}$ & $\begin{array}{l}\text { Radboud Medical } \\
\text { Centre, Nijmegen, } \\
\text { Netherlands }\end{array}$ \\
\hline
\end{tabular}

ALL, acute lymphoblastic leukemia; AML, acute myeloid leukemia; CB, cord blood; CLL, chronic lymphoblastic leukemia; CML, chronic myeloid leukemia; HL, Hodgkin lymphoma; HSCT, hematopoietic stem cell transplantation; MDS, myelodysplastic syndromes; MM, multiple myeloma; NHL, non-Hodgkin lymphoma; NK, natural killer; SLL, small lymphocytic lymphoma; UCB, umbilical cord blood. 
paving the way for NK cell adoptive immunotherapy. NK cells have shown great potential in eliminating different types of cancer cells in vitro and in animal models. A few clinical trials are currently underway to evaluate the safety and feasibility of using UCB NK cells as an "off the shelf" product for the prevention of relapse. The results from these studies will help in understanding how to maximize the beneficial potential of UCB NK cells for the treatment of hematological malignancies and solid tumors.

\section{REFERENCES}

1. Cooper MA, Fehniger TA, Caligiuri MA. The biology of human natural killer-cell subsets. Trends Immunol (2001) 22:633-40. doi:10.1016/ S1471-4906(01)02060-9

2. Burns LJ, Weisdorf DJ, Defor TE, Vesole DH, Repka TL, Blazar BR, et al. IL-2-based immunotherapy after autologous transplantation for lymphoma and breast cancer induces immune activation and cytokine release: a phase I/II trial. Bone Marrow Transplant (2003) 32:177-86. doi:10.1038/sj.bmt.1704086

3. Valiante NM, Parham P. Natural killer cells, HLA class I molecules, and marrow transplantation. Biol Blood Marrow Transplant (1997) 3:229-35.

4. Ruggeri L, Capanni M, Urbani E, Perruccio K, Shlomchik WD, Tosti A, et al. Effectiveness of donor natural killer cell alloreactivity in mismatched hematopoietic transplants. Science (2002) 295:2097-100. doi:10.1126/ science. 1068440

5. Miller JS, Soignier Y, Panoskaltsis-Mortari A, Mcnearney SA, Yun GH, Fautsch SK, et al. Successful adoptive transfer and in vivo expansion of human haploidentical NK cells in patients with cancer. Blood (2005) 105:3051-7. doi:10.1182/blood-2004-07-2974

6. Geller MA, Cooley S, Judson PL, Ghebre R, Carson LF, Argenta PA, et al. A phase II study of allogeneic natural killer cell therapy to treat patients with recurrent ovarian and breast cancer. Cytotherapy (2011) 13:98-107. doi:10.3109/14653249.2010.515582

7. Bachanova V, Burns LJ, Mckenna DH, Curtsinger J, Panoskaltsis-Mortari A, Lindgren BR, et al. Allogeneic natural killer cells for refractory lymphoma. Cancer Immunol Immunother (2010) 59:1739-44. doi:10.1007/ s00262-010-0896-z

8. Bachanova V, Cooley S, Defor TE, Verneris MR, Zhang B, Mckenna DH, et al. Clearance of acute myeloid leukemia by haploidentical natural killer cells is improved using IL-2 diphtheria toxin fusion protein. Blood (2014) 123:3855-63. doi:10.1182/blood-2013-10-532531

9. Ishikawa E, Tsuboi K, Saijo K, Harada H, Takano S, Nose T, et al. Autologous natural killer cell therapy for human recurrent malignant glioma. Anticancer Res (2004) 24:1861-71.

10. Tarek N, Le Luduec JB, Gallagher MM, Zheng J, Venstrom JM, Chamberlain E, et al. Unlicensed NK cells target neuroblastoma following anti-GD2 antibody treatment. J Clin Invest (2012) 122:3260-70. doi:10.1172/JCI62749

11. Sun J, Wang J, Pefanis E, Chao J, Rothschild G, Tachibana I, et al. Transcriptomics identify CD9 as a marker of murine IL-10-competent regulatory B cells. Cell Rep (2015) 13:1110-7. doi:10.1016/j.celrep.2015.09.070

12. Komanduri KV, St John LS, De Lima M, Mcmannis J, Rosinski S, Mcniece I, et al. Delayed immune reconstitution after cord blood transplantation is characterized by impaired thymopoiesis and late memory T-cell skewing. Blood (2007) 110:4543-51. doi:10.1182/blood-2007-05-092130

13. Kotylo PK, Baenzinger JC, Yoder MC, Engle WA, Bolinger CD. Rapid analysis of lymphocyte subsets in cord blood. Am J Clin Pathol (1990) 93:263-6. doi:10.1093/ajcp/93.2.263

14. Luevano M, Daryouzeh M, Alnabhan R, Querol S, Khakoo S, Madrigal A, et al. The unique profile of cord blood natural killer cells balances incomplete maturation and effective killing function upon activation. Hum Immunol (2012) 73:248-57. doi:10.1016/j.humimm.2011.12.015

15. Tanaka H, Kai S, Yamaguchi M, Misawa M, Fujimori Y, Yamamoto M, et al. Analysis of natural killer (NK) cell activity and adhesion molecules on NK cells from umbilical cord blood. Eur J Haematol (2003) 71:29-38. doi:10.1034/j.1600-0609.2003.00081.x

16. Dalle JH, Menezes J, Wagner E, Blagdon M, Champagne J, Champagne MA, et al. Characterization of cord blood natural killer cells: implications

\section{AUTHOR CONTRIBUTIONS}

All the authors contributed to writing and reviewing the manuscript.

\section{FUNDING}

This work was funded and supported by Anthony Nolan and the King Abdullah International Medical Research Center.

for transplantation and neonatal infections. Pediatr Res (2005) 57:649-55. doi:10.1203/01.PDR.0000156501.55431.20

17. Verneris MR, Miller JS. The phenotypic and functional characteristics of umbilical cord blood and peripheral blood natural killer cells. Br J Haematol (2009) 147:185-91. doi:10.1111/j.1365-2141.2009.07768.x

18. Cooley S, Mccullar V, Wangen R, Bergemann TL, Spellman S, Weisdorf $\mathrm{DJ}$, et al. KIR reconstitution is altered by $\mathrm{T}$ cells in the graft and correlates with clinical outcomes after unrelated donor transplantation. Blood (2005) 106:4370-6. doi:10.1182/blood-2005-04-1644

19. Nguyen S, Kuentz M, Vernant JP, Dhedin N, Bories D, Debre P, et al. Involvement of mature donor $\mathrm{T}$ cells in the $\mathrm{NK}$ cell reconstitution after haploidentical hematopoietic stem-cell transplantation. Leukemia (2008) 22:344-52. doi:10.1038/sj.leu.2405041

20. Gaddy J, Broxmeyer HE. Cord blood CD16+56- cells with low lytic activity are possible precursors of mature natural killer cells. Cell Immunol (1997) 180:132-42. doi:10.1006/cimm.1997.1175

21. Perez SA, Sotiropoulou PA, Gkika DG, Mahaira LG, Niarchos DK, Gritzapis AD, et al. A novel myeloid-like NK cell progenitor in human umbilical cord blood. Blood (2003) 101:3444-50. doi:10.1182/ blood-2002-05-1501

22. Rutella S, Bonanno G, Marone M, De Ritis D, Mariotti A, Voso MT, et al. Identification of a novel subpopulation of human cord blood CD34-CD133CD7-CD45+lineage- cells capable of lymphoid/NK cell differentiation after in vitro exposure to IL-15. J Immunol (2003) 171:2977-88. doi:10.4049/ jimmunol.171.6.2977

23. Wang Y, Xu H, Zheng X, Wei H, Sun R, Tian Z. High expression of NKG2A/ CD94 and low expression of granzyme B are associated with reduced cord blood NK cell activity. Cell Mol Immunol (2007) 4:377-82.

24. Satwani P, Van De Ven C, Ayello J, Cairo D, Simpson LL, Baxi L, et al. Interleukin (IL)-15 in combination with IL-2, fms-like tyrosine kinase-3 ligand and anti-CD3 significantly enhances umbilical cord blood natural killer (NK) cell and NK-cell subset expansion and NK function. Cytotherapy (2011) 13:730-8. doi:10.3109/14653249.2011.563292

25. Alnabhan R, Madrigal A, Saudemont A. Differential activation of cord blood and peripheral blood natural killer cells by cytokines. Cytotherapy (2015) 17:73-85. doi:10.1016/j.jcyt.2014.08.003

26. Escobedo-Cousin M, Jackson N, Laza-Briviesca R, Ariza-Mcnaughton L, Luevano M, Derniame S, et al. Natural killer cells improve hematopoietic stem cell engraftment by increasing stem cell clonogenicity in vitro and in a humanized mouse model. PLoS One (2015) 10:e0138623. doi:10.1371/journal. pone. 0138623

27. Schonberg K, Fischer JC, Kogler G, Uhrberg M. Neonatal NK-cell repertoires are functionally, but not structurally, biased toward recognition of self HLA class I. Blood (2011) 117:5152-6. doi:10.1182/ blood-2011-02-334441

28. Gaddy J, Risdon G, Broxmeyer HE. Cord blood natural killer cells are functionally and phenotypically immature but readily respond to interleukin-2 and interleukin-12. J Interferon Cytokine Res (1995) 15:527-36. doi:10.1089/ jir.1995.15.527

29. Lin SJ, Kuo ML. Cytotoxic function of umbilical cord blood natural killer cells: relevance to adoptive immunotherapy. Pediatr Hematol Oncol (2011) 28:640-6. doi:10.3109/08880018.2011.613092

30. Shah N, Martin-Antonio B, Yang H, Ku S, Lee DA, Cooper LJ, et al. Antigen presenting cell-mediated expansion of human umbilical cord blood yields log-scale expansion of natural killer cells with anti-myeloma activity. PLoS One (2013) 8(10):e76781. doi:10.1371/journal.pone. 0076781 
31. Ayello J, Hochberg J, Flower A, Chu Y, Baxi LV, Quish W, et al. Genetically re-engineered K562 cells significantly expand and functionally activate cord blood natural killer cells: potential for adoptive cellular immunotherapy. Exp Hematol (2017) 46:38-47. doi:10.1016/j.exphem.2016.10.003

32. Vasu S, Berg M, Davidson-Moncada J, Tian X, Cullis H, Childs RW. A novel method to expand large numbers of CD56(+) natural killer cells from a minute fraction of selectively accessed cryopreserved cord blood for immunotherapy after transplantation. Cytotherapy (2015) 17(11):1582-93. doi:10.1016/j. jcyt.2015.07.020

33. Luevano M, Madrigal A, Saudemont A. Generation of natural killer cells from hematopoietic stem cells in vitro for immunotherapy. Cell Mol Immunol (2012) 9:310-20. doi:10.1038/cmi.2012.17

34. Spanholtz J, Tordoir M, Eissens D, Preijers F, Van Der Meer A, Joosten I, et al. High log-scale expansion of functional human natural killer cells from umbilical cord blood CD34-positive cells for adoptive cancer immunotherapy. PLoS One (2010) 5:e9221. doi:10.1371/journal.pone.0009221

35. Spanholtz J, Preijers F, Tordoir M, Trilsbeek C, Paardekooper J, De Witte T, et al. Clinical-grade generation of active NK cells from cord blood hematopoietic progenitor cells for immunotherapy using a closed-system culture process. PLoS One (2011) 6:e20740. doi:10.1371/journal.pone.0020740

36. Luevano M, Domogala A, Blundell M, Jackson N, Pedroza-Pacheco I, Derniame S, et al. Frozen cord blood hematopoietic stem cells differentiate into higher numbers of functional natural killer cells in vitro than mobilized hematopoietic stem cells or freshly isolated cord blood hematopoietic stem cells. PLoS One (2014) 9:e87086. doi:10.1371/journal.pone.0087086

37. Cany J, Van Der Waart AB, Tordoir M, Franssen GM, Hangalapura BN, De Vries J, et al. Natural killer cells generated from cord blood hematopoietic progenitor cells efficiently target bone marrow-residing human leukemia cells in NOD/SCID/IL2Rg(null) mice. PLoS One (2013) 8:e64384. doi:10.1371/ journal.pone.0064384

38. Cany J, Van Der Waart AB, Spanholtz J, Tordoir M, Jansen JH, Van Der Voort $\mathrm{R}$, et al. Combined IL-15 and IL-12 drives the generation of CD34+-derived natural killer cells with superior maturation and alloreactivity potential following adoptive transfer. Oncoimmunology (2015) 4:e1017701. doi:10.1080/ 2162402X.2015.1017701

39. Domogala A, Madrigal JA, Saudemont A. Cryopreservation has no effect on function of natural killer cells differentiated in vitro from umbilical cord blood CD34(+) cells. Cytotherapy (2016) 18:754-9. doi:10.1016/j.jcyt.2016.02.008

40. Vivier E, Nunes JA, Vely F. Natural killer cell signaling pathways. Science (2004) 306:1517-9. doi:10.1126/science.1103478

41. Vilches C, Parham P. KIR: diverse, rapidly evolving receptors of innate and adaptive immunity. Annu Rev Immunol (2002) 20:217-51. doi:10.1146/ annurev.immunol.20.092501.134942

42. Leung W. Use of NK cell activity in cure by transplant. Br J Haematol (2011) 155:14-29. doi:10.1111/j.1365-2141.2011.08823.x

43. Bishara A, De Santis D, Witt CC, Brautbar C, Christiansen FT, Or R, et al. The beneficial role of inhibitory KIR genes of HLA class I NK epitopes in haploidentically mismatched stem cell allografts may be masked by residual donor-alloreactive T cells causing GVHD. Tissue Antigens (2004) 63:204-11. doi:10.1111/j.0001-2815.2004.00182.x

44. Hsu KC, Gooley T, Malkki M, Pinto-Agnello C, Dupont B, Bignon JD, et al. KIR ligands and prediction of relapse after unrelated donor hematopoietic cell transplantation for hematologic malignancy. Biol Blood Marrow Transplant (2006) 12:828-36. doi:10.1016/j.bbmt.2006.04.008

45. Ruggeri L, Mancusi A, Capanni M, Urbani E, Carotti A, Aloisi T, et al. Donor natural killer cell allorecognition of missing self in haploidentical hematopoietic transplantation for acute myeloid leukemia: challenging its predictive value. Blood (2007) 110:433-40. doi:10.1182/blood-2006-07-038687

46. Vago L, Forno B, Sormani MP, Crocchiolo R, Zino E, Di Terlizzi S, et al. Temporal, quantitative, and functional characteristics of single-KIR-positive alloreactive natural killer cell recovery account for impaired graft-versusleukemia activity after haploidentical hematopoietic stem cell transplantation. Blood (2008) 112:3488-99. doi:10.1182/blood-2007-07-103325

47. Venstrom JM, Gooley TA, Spellman S, Pring J, Malkki M, Dupont B, et al. Donor activating KIR3DS1 is associated with decreased acute GVHD in unrelated allogeneic hematopoietic stem cell transplantation. Blood (2010) 115:3162-5. doi:10.1182/blood-2009-08-236943

48. Brunstein CG, Wagner JE, Weisdorf DJ, Cooley S, Noreen H, Barker JN, et al. Negative effect of KIR alloreactivity in recipients of umbilical cord blood transplant depends on transplantation conditioning intensity. Blood (2009) 113:5628-34. doi:10.1182/blood-2008-12-197467

49. Willemze R, Ruggeri A, Purtill D, Rodrigues CA, Gluckman E, Rocha V, et al. Is there an impact of killer cell immunoglobulin-like receptors and KIR-ligand incompatibilities on outcomes after unrelated cord blood stem cell transplantation? Best Pract Res Clin Haematol (2010) 23:283-90. doi:10.1016/j. beha.2010.05.005

50. Garfall A, Kim HT, Sun L, Ho VT, Armand P, Koreth J, et al. KIR ligand incompatibility is not associated with relapse reduction after double umbilical cord blood transplantation. Bone Marrow Transplant (2013) 48:1000-2. doi:10.1038/bmt.2012.272

51. Tanaka J, Morishima Y, Takahashi Y, Yabe T, Oba K, Takahashi S, et al. Effects of KIR ligand incompatibility on clinical outcomes of umbilical cord blood transplantation without ATG for acute leukemia in complete remission. Blood Cancer J (2013) 3:e164. doi:10.1038/bcj.2013.62

52. Willemze R, Rodrigues CA, Labopin M, Sanz G, Michel G, Socie G, et al. KIRligand incompatibility in the graft-versus-host direction improves outcomes after umbilical cord blood transplantation for acute leukemia. Leukemia (2009) 23:492-500. doi:10.1038/leu.2008.365

53. Sekine T, Marin D, Cao K, Li L, Mehta P, Shaim H, et al. Specific combinations of donor and recipient KIR-HLA genotypes predict for large differences in outcome after cord blood transplantation. Blood (2016) 128:297-312. doi:10.1182/blood-2016-03-706317

54. Cooley S, Trachtenberg E, Bergemann TL, Saeteurn K, Klein J, Le CT, et al. Donors with group B KIR haplotypes improve relapse-free survival after unrelated hematopoietic cell transplantation for acute myelogenous leukemia. Blood (2009) 113:726-32. doi:10.1182/blood-2008-07-171926

55. Cooley S, Weisdorf DJ, Guethlein LA, Klein JP, Wang T, Le CT, et al. Donor selection for natural killer cell receptor genes leads to superior survival after unrelated transplantation for acute myelogenous leukemia. Blood (2010) 116:2411-9. doi:10.1182/blood-2010-05-283051

56. Cooley S, Weisdorf DJ, Guethlein LA, Klein JP, Wang T, Marsh SG, et al. Donor killer cell Ig-like receptor B haplotypes, recipient HLA-Cl, and HLA-C mismatch enhance the clinical benefit of unrelated transplantation for acute myelogenous leukemia. J Immunol (2014) 192:4592-600. doi:10.4049/ jimmunol.1302517

57. Kim S, Poursine-Laurent J, Truscott SM, Lybarger L, Song YJ, Yang L, et al. Licensing of natural killer cells by host major histocompatibility complex class I molecules. Nature (2005) 436:709-13. doi:10.1038/ nature 03847

58. Shifrin N, Raulet DH, Ardolino M. NK cell self tolerance, responsiveness and missing self recognition. Semin Immunol (2014) 26:138-44. doi:10.1016/j. smim.2014.02.007

59. Anfossi N, Andre P, Guia S, Falk CS, Roetynck S, Stewart CA, et al. Human NK cell education by inhibitory receptors for MHC class I. Immunity (2006) 25:331-42. doi:10.1016/j.immuni.2006.06.013

60. Cooley S, Xiao F, Pitt M, Gleason M, Mccullar V, Bergemann TL, et al. A subpopulation of human peripheral blood NK cells that lacks inhibitory receptors for self-MHC is developmentally immature. Blood (2007) 110:578-86. doi:10.1182/blood-2006-07-036228

61. Orr MT, Murphy WJ, Lanier LL. 'Unlicensed' natural killer cells dominate the response to cytomegalovirus infection. Nat Immunol (2010) 11:321-7. doi:10.1038/ni.1849

62. Yoon SR, Lee YS, Yang SH, Ahn KH, Lee JH, Lee JH, et al. Generation of donor natural killer cells from CD34(+) progenitor cells and subsequent infusion after HLA-mismatched allogeneic hematopoietic cell transplantation: a feasibility study. Bone Marrow Transplant (2010) 45:1038-46. doi:10.1038/ bmt.2009.304

Conflict of Interest Statement: The authors declare that the research was conducted in the absence of any commercial or financial relationships that could be construed as a potential conflict of interest.

Copyright $\odot 2017$ Sarvaria, Jawdat, Madrigal and Saudemont. This is an open-access article distributed under the terms of the Creative Commons Attribution License (CC $B Y)$. The use, distribution or reproduction in other forums is permitted, provided the original author(s) or licensor are credited and that the original publication in this journal is cited, in accordance with accepted academic practice. No use, distribution or reproduction is permitted which does not comply with these terms. 